Vol. 3, No. 1, 2016

UDC 330.341

A. G. Zahorodniy

$\mathrm{PhD}$ of Economic Sciences, Professor,

S. Ya. Babinska

Postgraduate student

Lviv Polytechnic National University

\title{
PARTICIPANTS OF AN INNOVATIVE PROJECT: THEIR TASKS, CONTRIBUTIONS AND INTERESTS
}

\begin{abstract}
The article considers the role of participants of the innovative project in its implementation, contractor relations, information, financial, and material flows that arise between them and accompany the process of the project implementation. Contributions and interests of participants in terms of the theory of groups of economic influence (stakeholders) and the conditions necessary for the successful implementation of an innovative project are investigated.
\end{abstract}

Key words: innovative project, participants of innovative project, asymmetry of information, groups of economic influence (stakeholders).

\section{Problem statement}

Under conditions of competitive economy innovation projects are an important factor in developing enterprise activities and attracting foreign investments into the country. Their essence consists in implementing measures directed towards application of innovative developments, developing new products, introducing new technologies for strengthening competitive position of the company in the market; promoting scientific and technological progress and raising the rate of economic development. In implementation of any innovation project, even the smallest ones, there take part several dozens of participants. If it is a big project, their number may reach several hundreds. So, research into the tasks set before the participants of the innovative project, their contributions and interests in the process of implementation of the project is relevant and expedient.

\section{Analysis of the recent research and publications}

The issues related to the implementation of innovative projects are dealt with in the works of the following domestic and foreign scientists:
I. Blanc [1] M. Denysenko [2], P. Zavlin [3], S. Illiashenko [4], A. Kazantsev, [5], N. Krasnokutska [6], O. Kuzmin [7], H. Merkulov [8], L. Mindeli [5], P. Khariv [9], A. Yakovliev [10] and others. However, some aspects concerning participants and their tasks, contributions and interests of the groups of economic influence involved in the innovative project implementation have been studied insufficiently and need further research.

The purpose of this research is to define the tasks of the innovative project participants and their contributions into the project implementation as well as their interests in it.

\section{Material presentation}

To ensure competitive advantages of the enterprise and to improve its functioning it is necessary to create favorable conditions for the implementation of innovative projects. Participants play a significant role in the process of implementing innovative projects. Depending on the specifics, the size and type of the project a large number of organizations may participate in its implementation, each of these organizations performing certain functions and being responsible for the results of their activities. Fig. 1 shows the main participants of the innovation project.

The main participant of the innovative project is its executor, i.e. a physical or legal person which implements a project to achieve its main goal. There is a constant motion of information, cash, products, services, and works between the project executor and other participants of the project. Table 1 shows the innovative project participants and their main tasks in the process of project implementation. 
A. G. Zahorodniy, S. Ya. Babinska

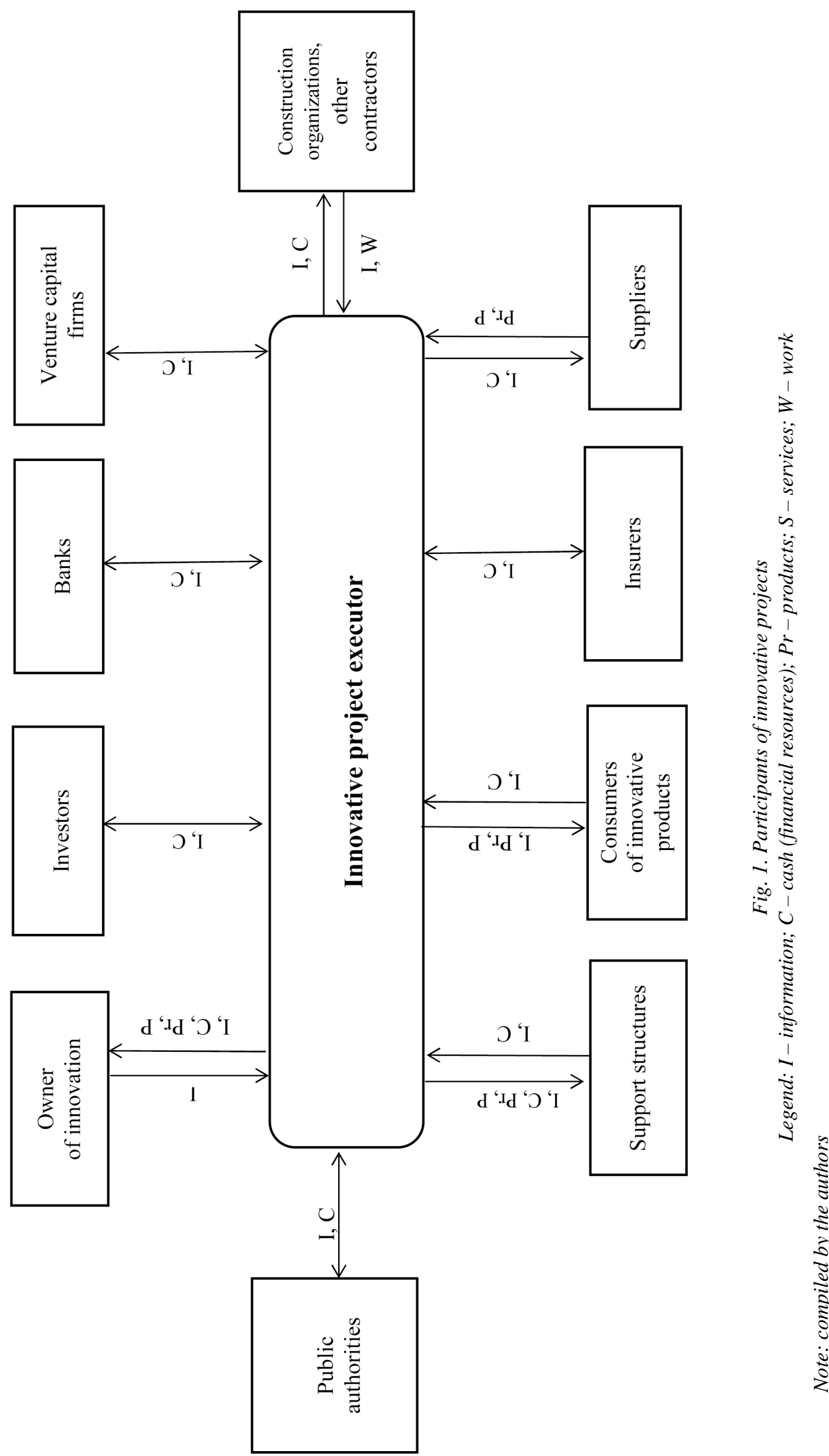


The innovative project participants and their tasks

\begin{tabular}{|c|c|}
\hline Types of participants & Main tasks \\
\hline Innovative project executor & $\begin{array}{l}\text { - implementing the main purpose of the innovation project } \\
\text { - attracting investors for implementation of the innovative project }\end{array}$ \\
\hline Owner of innovation & $\begin{array}{l}\text { - providing the project executor with the information on the innovative project that } \\
\text { defines the basic requirements and characteristics of innovation }\end{array}$ \\
\hline Investors & $\begin{array}{l}\text { - investing their own (borrowed) property and intellectual assets in the innovative } \\
\text { project for getting profit }\end{array}$ \\
\hline Banks & $\begin{array}{l}\text { - opening and keeping current accounts of the project participants } \\
\text { - making settlements between the project participants } \\
\text { - providing loans to the project participants } \\
\text { - operating on investments } \\
\text { - being intermediaries in carrying on leasing operations } \\
\text { - - consulting on banking and other financial services }\end{array}$ \\
\hline Venture capital firms & $\begin{array}{l}\text { - creating and implementing new types of products, new techniques and } \\
\text { technologies, using a venture capital (venture financing is provided without any } \\
\text { pledges unlike the bank crediting) } \\
\text { - attracting resources for implementation of innovation activity } \\
\text { - realizing results of the applied research }\end{array}$ \\
\hline $\begin{array}{l}\text { Construction organizations, } \\
\text { other contractors }\end{array}$ & $\begin{array}{l}\text { - developing the project estimate } \\
\text { - building new facilities, reconstructing, overhauling or expanding the existing ones, } \\
\text { and installing equipment under the contract concluded with the innovative project } \\
\text { executor } \\
\text { - engaging subcontractors to perform certain types of work }\end{array}$ \\
\hline Suppliers & $\begin{array}{l}\text { - providing material and technical support necessary for implementation of the } \\
\text { innovative project }\end{array}$ \\
\hline Insurers (insurance company) & $\begin{array}{l}\text { - providing the project participants property interests protection } \\
\text { - being obligated, for a certain fee, to compensate to the policyholders and other } \\
\text { participants of insurance market the loss inflicted by the insured event or to pay the } \\
\text { insured amount during the period identified by the contract }\end{array}$ \\
\hline Consumers of innovative products & $\begin{array}{l}\text { - purchasing the products and services that are the result of implementing innovative } \\
\text { projects }\end{array}$ \\
\hline Support structures & $\begin{array}{l}\text { - facilitating the innovative project implementation by providing the project executor } \\
\text { with the information, money, products or services that are needed. }\end{array}$ \\
\hline $\begin{array}{l}\text { Public authorities (Verkhovna Rada of } \\
\text { Ukraine, the Cabinet of Ministers of } \\
\text { Ukraine, central executive power } \\
\text { bodies, authorities of local govern- } \\
\text { ment (village, town and city councils)) }\end{array}$ & $\begin{array}{l}\text { - determining the legal, economic and organizational foundations of state regulation } \\
\text { of innovation activity in Ukraine } \\
\text { - establishing forms of stimulating innovation processes } \\
\text { - providing the project executor with the information and funding some innovative } \\
\text { projects }\end{array}$ \\
\hline
\end{tabular}

Note: compiled by the authors

As to innovative projects funding, it should be noted that according to [11], the amount of funds directed towards their financing should not exceed $70 \%$ of the project cost. This provision also says that the enterprise own funds should constitute not less that $30 \%$ of the innovation project financing. The amount of funds from the State budget that are allocated for financing one innovative project may not be less than 200 thousand UAH. The innovative projects that are supposed to get financial support from the state budget are selected by Credit Council of Ukrainian State Innovation Company.
Information is an important resource being exchanged between the project executor and all its participants. It plays an important role in the process of designing and implementing innovative projects because the process directly requires the availability of complete, accurate, timely and relevant information about the market, demand for products, market conditions, competitors etc. However, for the information to be usable it should be, first of all, gathered and made available to users.

However, a significant disadvantage, which may arise in the process of the innovative project 


\section{A. G. Zahorodniy, S. Ya. Babinska}

implementation and be related to the information and its movement is asymmetry of information. According to the definition provided by "Financial and economic dictionary" [12], asymmetry of information is "the situation, in which some market participants possess the information, which is not available to other interested parties". This phenomenon covers various areas of activities, including innovation activities of enterprises. Asymmetry of information results in reducing the effectiveness of the decisions made by the innovative projects participants and increasing the innovative projects implementation risks. In fact, the users of information have different goals, and therefore, each innovative project participant has different material interests.

Thus, for example, B. Eichengreen [13], the famous economist, Professor at University of California, considers that due to the information environment asymmetry investors are faced with difficult task of choosing the direction of investments, because when reliable and accurate information is not available it is difficult for them to determine when and how the information asymmetry will affect their business.

These are the disadvantages of the information asymmetry [14]:

- the market equilibrium (both favorable and unfavorable), being the balanced state of the market, is changing under the influence of the information asymmetry;

- the information asymmetry leads to the emergence of defects in market participants interactions, thus undermining the optimal allocation of resources. In commodity markets the information asymmetry results in developing negative trends;

- the effect of information asymmetry reduces the efficiency of the economy as a whole and affects its security. The most skillful and conscientious participants of market relations are advantageous therefore the benefits of society from the effects of information asymmetry largely exceed its losses, otherwise the losses from the effects of asymmetry information are very considerable for society. The fact that the economy is characterized by the low level of information capacity has the negative impact on the economic security of the state.

Asymmetry of information has the following effects: consumers of innovative products purchase lower quality products at higher prices; sellers of better quality goods experience reduced sales. If such a situation lasts for quite a long time, it will lead to bankruptcy of best sellers, so the asymmetry of information is dangerous for the market.

Each group of participants (the owner of innovation, investors, banks, venture capital firms, construction organizations and other contractors, suppliers, insurers, consumers, support structures, public authorities and other participants) affects the implementation of innovative projects so they can be considered the groups of economic influence (stakeholders). E. Freeman [15, p. 46] provided the following definition of the groups of economic influence (Engl. stakeholders): these are groups of people or organizations (economic entities) that can either resist or contribute to the goals or activities of an organization.

By the environment to which stakeholders belong, they are usually divided into internal (the owner of innovation) and external (investors, banks, venture capital firms, construction organizations other contractors, suppliers, insurers, consumers, support structures, public authorities). Groups of economic influence can have both financial and non-financial impact on the implementation of innovative projects.

Each group of economic influence has some relation to and interest in the innovative project that is demonstrated in financial, material and technical, insurance or other forms. Accordingly, to implement the project successfully the innovative project executor should pay due attention to the contributions and interests of each group of economic influence and coordinate them. However, in Ukraine accounting the interests of groups of economic influence in most cases is done intuitively because of the lack of effective tools for their considering.

Contributions of stakeholders in the implementation of innovative projects and their interests in their implementation are shown in fig. 2 and fig. 3, respectively.

As seen from fig. 2 and fig. 3, each group of stakeholders makes certain contribution to the innovative project implementation, and also has an interest in its implementation. It is apparent that each of the groups is interested in successful implementation of the innovative project. Therefore, to avoid possible negative consequences that may arise in the process of implementing the 


\section{Participants of an Innovative Project: Their Tasks, Contributions and Interests}

innovative project it is necessary to adhere to the following conditions:

- to reduce the risk of the information asymmetry occurrence;

- to involve highly qualified specialists to the project implementation;

- to organize interaction, in particular, exchange of information, among the innovative project participants and to coordinate their interests;
- to create the situation when the participants' interests coincide with the project goal;

- to create the database containing information on innovative projects and to timely update it. An important element of this base is its connection with information centers, databases (including foreign) and its ability to provide the interested parties and individuals or organizations interested in financing the innovative projects etc. with the access to the necessary information.

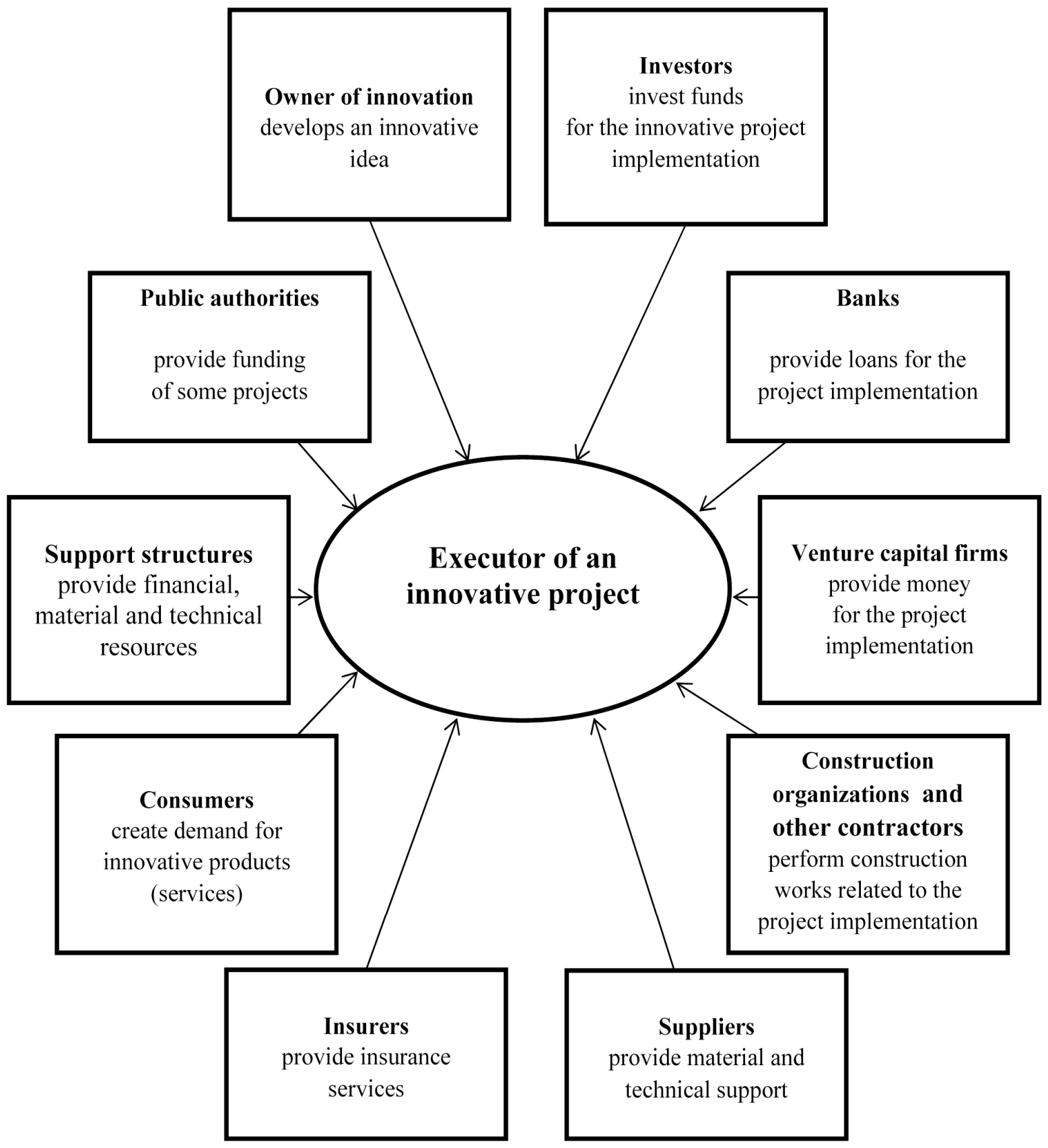

Fig. 2. Contributions of the groups of economic influence (stakeholders) into the innovative project implementation

Note: compiled by the authors 


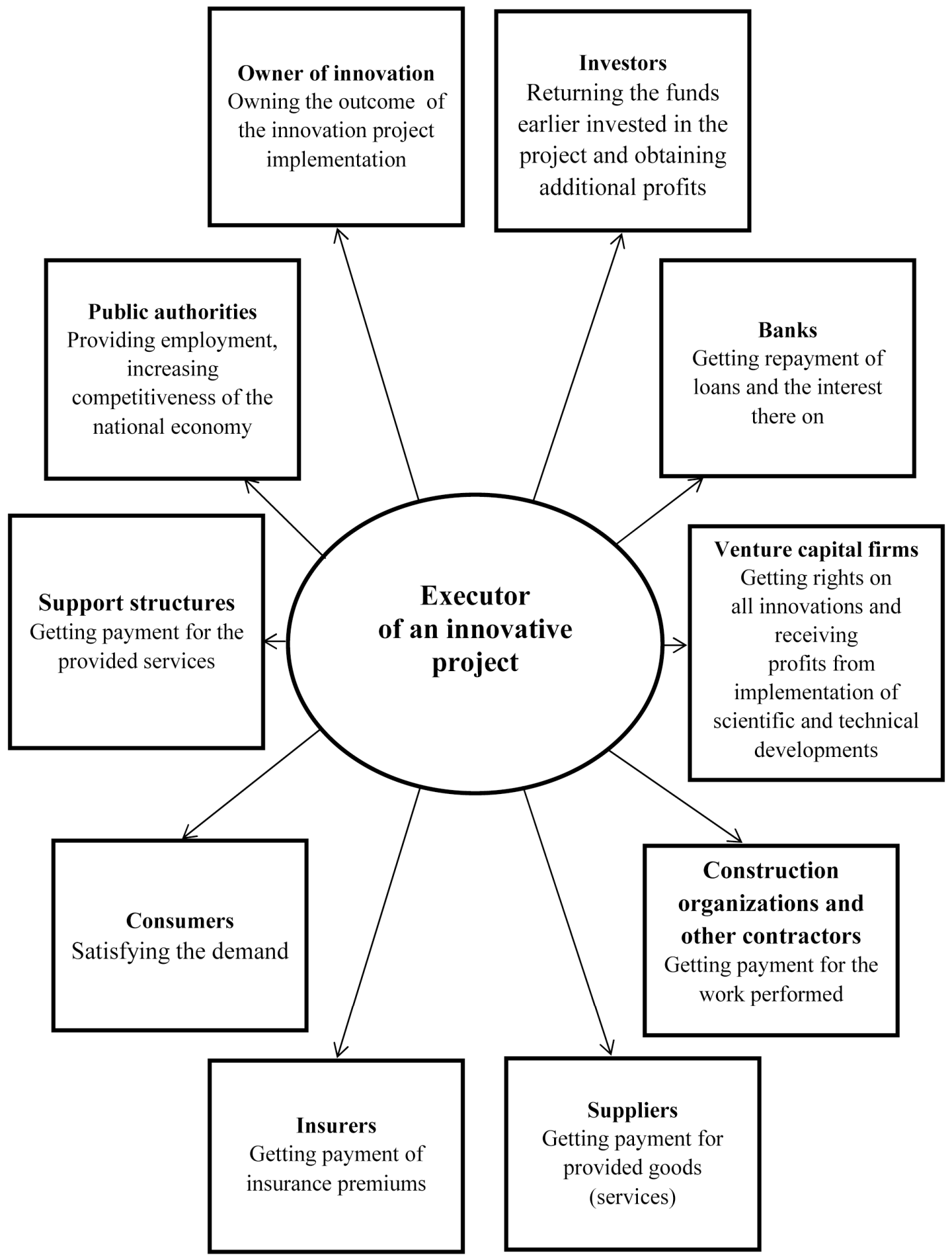

Fig. 3. Interests of groups of economic influence (stakeholders) in the innovative project implementation

Note: compiled by the authors

\section{Conclusions}

The innovative projects development and implementation take an important place in scientific and technological progress of the country. In fact, implementation of innovative projects grants any company the status of being flexibile and innovative thus strengthening its competitive position and increasing the rate of economic development of the enterprise. However, for the successful implementation of the project it 
is necessary to ensure coordination of work (planning, organization, control) of the project participants, adjustment of their contributions and interests within the innovative project, taking into account the tasks of each participant and providing them with all necessary and sufficient information to avoid information asymmetry. All this is necessary for the successful innovative project implementation that, to a large extent, depends upon the project participants and the information they possess.

\section{References}

1. Blanc I. A. (1999) Fundamentals of Financial Management. - K.: Nika Tsentr.

2. Denysenko M. P., Holubieva T. S., Kolos I. V. (2009) Information provision of innovative investment activities of company. Management and enterprise in Ukraine: stages establishment of and problems development, pp. 43-49.

3. Zavlin P. N. (2000) Foundations of innovation management: theory and practice. - M.: OAO "NPO "Izdatelstvo "Ekonomika".

4. Illiashenko S. M. (2003) Management of innovation development: problems, concepts, methods. Sumy: VTD "Universytetska knyha".

5. Kazantsev A. K., Mindeli L. E. (2004) Fundamentals of innovation management. - M.: Zao "Izdatelstvo "Ekonomika".
6. Krasnokutska N. V. (2003) Innovation management. $K .: K N E U$.

7. Kuzmin O. Ye., Kniaz S. V., Vivchar O. Y., Melnyk L. I. (2005) Activation of investment and innovation activities of enterprises. - Stryi: TzOV "Ukrpol".

8. Merkulov N. N. (2007) Scientific technological activity: innovative aspects. Odessa.

9. Khariv P. S. (2003) Innovation activity of enterprise and economic evaluation of innovative processes. Ternopil: Ekonomichna dumka.

10. Yakovliev A. I. (2010) Project analysis of innovative investment activities. - Kharkiv: NTU "KhPI".

11. "About approval of procedure using the special fund of the state budget of Ukraine directed to the financial support of innovation activities of business entities", [Electronic resource]/ - Access mode: http://zakon5.rada.gov.ua/laws/show/1316-2004-p

12. Zahorodniy A. G., Vozniuk G. L. (2011) Financial and economic dictionary. - Lviv: Vydavnytstvo Lvivskoi politekhniky.

13. Eichengreen B. (2003). Capital flows and crises. Cambridge: MIT Press, Massachusetts. -385 p.

14. Yevdokymov V. V. The asymmetry of accounting information and ways of her minimize. International collection of scientific papers, Vol. 3, No. 21, pp. 135-146.

15. Freeman R. E. (1984). Strategic Management: A Stakeholder Approach. Boston et al.: Pitman. $315 p$. 
